\title{
An Anomaly of Insulin Removal in Perfused Livers of Obese-Hyperglycemic (ob/ob) Mice
}

\author{
Clairette Karakash, Françoise Assimacopoulos-Jeannet, and \\ Bernard Jeanrenaud \\ From the Laboratoires de Recherches Médicales, Division de Diabétologie et \\ de Biochimie Clinique, and the Département de Médecine, Geneva University \\ Medical School, 1211 Geneva 4, Switzerland
}

\begin{abstract}
A в S T R A C T Obese-hyperglycemic (ob/ob) mice have the interesting feature of being hyperinsulinemic, thus having some characteristics in common with human maturity-onset diabetics. As the cause of hyperinsulinemia in these mice is not established, and as the liver is known to play a role in determining the amount of hormone that reaches the periphery, it was hypothesized that an anomaly in the hepatic handling of insulin might prevail in obese-hyperglycemic mice. Immunoreactive insulin was therefore measured in the perfusate before and after a single passage through perfused livers of lean and $o b / o b$ mice, permitting the calculation of insulin removal. It was found that the removal of insulin by livers of lean mice increased with increasing concentrations of the hormone in the portal vein. The removal process had a limited capacity, however, and as a consequence the percentage of hormone removed by the liver actually decreased when portal insulin concentrations increased. Insulin removal by livers of $o b / o b$ mice had qualitatively the same characteristics but was considerably less efficient than in normal livers. Due to this, more insulin was found in the perfusate leaving the liver of $o b / o b$ mice than in that of controls, at any insulin concentration tested. These observations suggest that in obese-hyperglycemic mice more of the hormone may reach the periphery and thus contribute to hyperinsulinemia. The present study further suggests that the anomaly of insulin removal observed in perfused livers of $o b / o b$ mice might be secondary to hyperinsulinemia, since it was partly corrected upon artificially decreasing the circulating levels of insulin (e.g. via a fast, anti-
\end{abstract}

This work was presented in part at the 10th Annual Meeting of the European Association for the Study of Diabetes, Jerusalem, September 1974.

Address mail to: Laboratoires de Recherches Médicales, Avenue de la Roseraie, 1205 Geneva, Switzerland.

Received for publication 17 March 1975 and in revised form 1 December 1975.

The Journal of Clinical Investigation Volume 57 May 1976.1117-1124 insulin serum, or streptozotocin treatment) before perfusion. The characteristics of hepatic insulin removal reported in this study, as well as the differences observed between livers of lean and $o b / o b$ mice, may reflect changes in membrane insulin receptors and/or in processes responsible for the degradation of the hormone.

\section{INTRODUCTION}

The liver has been shown to be important in determining the amount of insulin reaching the peripheral blood. Several in vivo investigations carried out in man and dog indicate that this organ removes significant quantities of insulin (1-4). This has been further substantiated in the rat by measurement of insulin removal in vitro by liver perfusion techniques (5-9). Such in vitro studies have suggested that the insulin removal was greater when less insulin reached the liver $(10,11)$. Moreover, when circulating insulin levels of normal rats were decreased by fasting or streptozotocin treatment, the removal of insulin by subsequently isolated livers was greater than in livers obtained from fed normal controls $(10,11)$, and was restored towards values observed in control livers by feeding or by administration of insulin, respectively (11).

Hyperinsulinemia is one of the main feature of the syndrome of the obese-hyperglycemic $(o b / o b)$ mice (12), and it appears to be of prime importance for the development of obesity in these animals $(13,14)$. It was therefore hypothesized that livers of the $o b / o b$ mice might be abnormal in their handling of insulin, and that such an anomaly might contribute to peripheral hyperinsulinemia.

\section{METHODS}

Animals. 8 or 11-wk-old male obese-hyperglycemic (C57 $\mathrm{BL} / 6 \mathrm{~J} o b / o b)$ mice purchased from the Jackson Laboratories, Bar Harbor, Me., and lean control (C57BL/6J ++/ ++) 
mice, bred in these laboratories, were used throughout these studies. Obese-hyperglycemic mice were made insulindeficient by intraperitoneal injection (after a 24-h fast) of $200 \mathrm{mg} / \mathrm{kg}$ streptozotocin diluted in $0.9 \% \mathrm{NaCl}$, acidified ( $\mathrm{pH} 4$ ) with $0.05 \mathrm{M}$ citric acid, or by the administration of anti-insulin serum (AIS) ${ }^{1}(0.1 \mathrm{ml}$, neutralizing capacity of $2.16 \mathrm{U} / \mathrm{ml}$ ) injected into a tail vein $2 \mathrm{~h}$ before the experiment. Lean mice were made insulin deficient by AIS injection only $(0.05 \mathrm{ml}$ i.v. $)$. All animals were fed ad libitum with laboratory chow or fasted for various durations as specified for each different experiment.

Perfusion technique. Mice were anesthetized by intraperitoneal injection of pentobarbital $(100 \mathrm{mg} / \mathrm{kg})$. Samples of blood were taken from the retro-orbital sinus for measurements of plasma glucose and insulin levels, and livers were subsequently perfused in situ by the method of Assimacopoulos-Jeannet et al. (15).

The perfusion medium was a Krebs-Ringer bicarbonate buffer, containing $3 \%$ bovine serum albumin, defatted with charcoal by the method of Chen (16), and $20 \%$ washed bovine erythrocytes. The perfusion medium was not recirculated, all experiments being thus carried out with the so-called "flow-through" technique. After a preperfusion period of $15 \mathrm{~min}$, porcine insulin diluted in $\mathrm{NaCl} 0.9 \%$ containing $1 \%$ human serum albumin was infused at constant rate into the medium entering the liver. The perfusate leaving the liver was collected every $3 \mathrm{~min}$ in a fraction collector.

Measurements. Immunoreactive insulin was determined in the perfusate before and after a single passage through the liver by the method of Herbert et al. (17), with antipork insulin antibody and pork insulin standards. For the measurement of plasma insulin levels, mouse or rat insulin standards were used. Glucose was determined by the glucose oxidase method (Biochemica Test combination kit, C. F. Boehringer and Sons, Mannheim, W. Germany).

Calculations. Wet liver weights of $o b / o b$ mice are about twice those of controls (controls : $1.29 \mathrm{~g} \pm 0.03 \mathrm{SEM}$; $o b / o b$ : $2.71 \mathrm{~g} \pm 0.07 ; n=13$ ). Due to this, flow rates were adjusted to be twice as great in perfused livers of $o b / o b$ mice as in those of controls (controls: $1.5 \mathrm{ml} / \mathrm{min}$; $o b / o b$ mice : 3.0 $\mathrm{ml} / \mathrm{min}$ ). Such a procedure is validated (Table I) by the finding that hepatic extraction of insulin was not affected by doubling the flow rate. For each experiment, calculations were thus made with individually measured flow rates, wet

${ }^{1}$ Abbreviation used in this paper: AIS, anti-insulin serum. liver weights, and insulin concentrations present in the perfusate entering $\left(\mathrm{cI}_{1 \mathrm{n}}\right)$ and leaving ( $\mathrm{cI}_{\text {out }}$ ) the liver, i.e.: c $I_{\text {in }} \times$ flow rate/liver weight $=I_{\text {in }}(\mathrm{ng} / \mathrm{g} / \mathrm{min}) ; c I_{\text {out }} \times$ flow rate/liver weight $=\mathrm{I}_{\text {out }}(\mathrm{ng} / \mathrm{g} / \mathrm{min})$.

Expression of results per gram of wet liver weight is justified, as the protein concentration of livers was found to be the same in both lean and $o b / o b$ mice (controls 147.3 $\pm 7.8 \mathrm{mg} / \mathrm{g}$ liver; $o b / o b \quad 138.5 \pm 5.7 ; n=4)$. Others have previously reported that protein and DNA concentrations were similar in livers of both lean and $o b / o b$ mice (18). It is assumed in the present experiments that the lipid concentration of livers (controls, $15 \pm 2 \mathrm{mg}$ triglyceride/g liver; $o b / o b$, up to $151 \pm 12 ; n=12$ ) is not implicated in the removal process, since the latter represents a complex phenomenon including binding to receptors, degradation, and uptake, processes likely to involve protein components and not inert membrane-free intracellular triglyceride droplets. These experiments, however, have to be read with such an assumption in mind.

The difference $I_{\text {in }}-I_{\text {out }}$, measured as described above, represents the absolute removal of insulin. As shown by Fig. 1, after infusion of insulin, the level of the hormone in the perfusate leaving the liver rose rapidly until a plateau was reached. The initial rapid phase probably accounts for binding of the hormone to the receptors, as previously suggested (9), while the plateau phase might reflect a dynamic equilibrium between several processes, including insulin degradation and displacement from binding sites. The plateau phase was obtained with both low and high concentrations of infused insulin, and with livers from either lean or $o b / o b$ mice. Insulin removal was thus calculated at the steady state from the plateau values and expressed as nanograms per gram per minute. To compare livers exposed to various concentrations of the hormone, the removal was also expressed as percent of insulin infused into the ingoing medium. All results were analyzed statistically by Student's $t$ test.

Chemicals. Insulin (pork Iletin U-100) was obtained from Eli Lilly and Company, Indianapolis, Ind. Insulin standards and labeled insulin were kindly supplied by the Institut de Biochimie Clinique, Geneva (Switzerland). AIS was a gift of Dr. Peter Wright, Indiana University School of Medicine, Indianapolis, Ind. Bovine serum albumin was obtained from Behringwerke AG, Marburg-Lann, W. Germany, and human serum albumin from the Croix Rouge Suisse, Berne, Switzerland. Streptozotocin was a gift of Dr. W. E. Dulin, Upjohn Co., Kalamazoo, Mich. All other chemicals were of analytical grade and were purchased from

TABLE I

Lack of Effect of the Flow Rate upon Insulin Removal by Perfused Livers from Lean and ob/ob Mice

\begin{tabular}{ccccccc}
\hline Animals & Liver weight & Flow rate & $I_{\text {in }}$ & $I_{\text {out }}$ & $I_{\text {in }}-I_{\text {out }}$ & Insulin removal \\
\hline \multirow{2}{*}{ Lean } & $g$ & $m l / m i n$ & $n g / g / m i n$ & $n g / g / m i n$ & $n g / g / m i n$ & $\%$ \\
& $1.16 \pm 0.03$ & 1.5 & $2.03 \pm 0.08$ & $1.07 \pm 0.07$ & $0.96 \pm 0.05$ & $47.3 \pm 2.4$ \\
\multirow{2}{*}{$o b / o b$} & 3 & $1.99 \pm 0.07$ & $1.00 \pm 0.07$ & $0.99 \pm 0.03$ & $49.8 \pm 2.3$ \\
& $2.28 \pm 0.08$ & 3 & $3.38 \pm 0.17$ & $2.17 \pm 0.11$ & $1.21 \pm 0.24$ & $35.7 \pm 5.0$ \\
& & 6 & $3.28 \pm 0.11$ & $2.06 \pm 0.01$ & $1.22 \pm 0.12$ & $37.1 \pm 2.6$ \\
\hline
\end{tabular}

Livers of 8-wk-old lean and $o b / o b$ mice were perfused for 45 min with a nonrecirculating medium, as described in Fig. 1 . After a 15-min preperfusion without hormone, pork insulin was infused at a constant rate into the portal vein to obtain the concentrations indicated. Insulin was determined in the perfusate entering the liver $\left(\mathrm{I}_{\text {in }}\right)$ and leaving it $\left(\mathrm{I}_{\text {out }}\right)$ after one passage through the organ. Insulin removal was determined at the steady state as detailed in Methods. Values are the means of three experiments \pm SEM. 


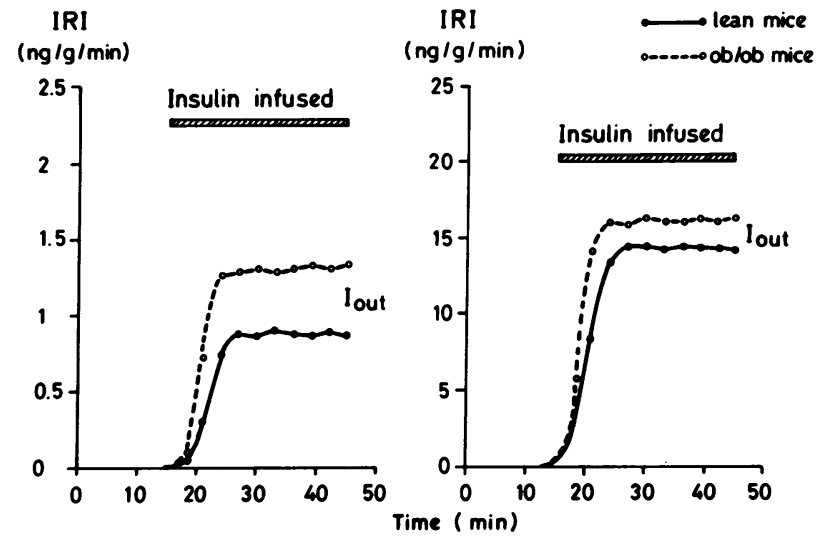

FIGURE 1 Time-course of insulin removal by perfused livers of 8-wk-old lean ( $\bullet$ ) and $o b / o b(\mathrm{O}--\mathrm{O})$ mice. Livers were perfused with a nonrecirculating medium consisting of Krebs-Ringer bicarbonate buffer with $3 \%$ defatted bovine serum albumin and $20 \%$ bovine erythrocytes. The flow rates were adjusted to $1.5 \mathrm{ml} / \mathrm{min}$ for livers of lean mice and $3 \mathrm{ml} / \mathrm{min}$ for livers of $o b / o b$ mice. After a 15-min preperfusion without hormone, pork insulin was infused (hatched bars) at constant rates into the portal vein to obtain concentrations of $2.3 \mathrm{ng} / \mathrm{g} / \mathrm{min}$ (left panel) and $20 \mathrm{ng} / \mathrm{g} / \mathrm{min}$ (right panel), respectively. Insulin was determined in the perfusate entering the liver and, at various time intervals, in the perfusate leaving it after one passage. Insulin removal was calculated as the difference between the concentration of insulin infused $\left(I_{1 n}\right)$ and insulin present in the perfusate leaving the liver $\left(\mathrm{I}_{\text {out }}\right)$, at the steady state (see Methods). Each point is the mean of at least four experiments. IRI, immunoreactive insulin.

E. Merck AG, Darmstadt, W. Germany, or Sigma Chemical Co., St. Louis, Mo.

\section{RESULTS}

Effect of the concentration of infused insulin upon its removal by perfused livers. As can be seen in Table II, the absolute amount of insulin removed after one passage through the liver increased with increasing concentrations of the hormone infused into the portal vein. This was true for livers of both lean and $o b / o b$ mice. However, at each insulin concentration, the removal of the hormone by livers of $o b / o b$ mice was always significantly less than that of controls. As a consequence, and as illustrated by Fig. 2, the percentage of the insulin removed by the liver was, at all insulin concentrations tested, considerably lower in livers of $o b / o b$ than in livers of control mice. It has been shown (Table I) that insulin removal was not affected by flow rates. To substantiate further that the observed differences of insulin removal between livers of lean and $o b / o b$ mice were indeed a real phenomenon, the following experiment was carried out. At perfusion time, livers of $o b / o b$ mice were ligated to exclude from circulation and to remove surgically half of their mass. Under these condi-
TABLE II

Effect of Increasing Concentrations of Insulin Infused into the Portal Vein upon its Removal by Perfused Livers of Lean and ob/ob Mice

\begin{tabular}{cccc}
\hline Anim $: 1 s$ & $\mathrm{I}_{\text {in }}$ & Iout & $\mathrm{I}_{\text {in }}-\mathrm{I}_{\text {out }}$ \\
\hline \multirow{3}{*}{ Lean } & $n g / \mathrm{g} / \mathrm{min}$ & $n g / \mathrm{g} / \mathrm{min}$ & $n g / \mathrm{g} / \mathrm{min}$ \\
& $2.49 \pm 0.07$ & $1.01 \pm 0.05$ & $1.48 \pm 0.06$ \\
& $4.99 \pm 0.15$ & $2.22 \pm 0.14$ & $2.77 \pm 0.15$ \\
& $10.03 \pm 0.44$ & $5.99 \pm 0.75$ & $4.04 \pm 0.26$ \\
& $20.01 \pm 1.35$ & $14.45 \pm 1.26$ & $5.56 \pm 0.91$ \\
& & & \\
& $2.51 \pm 0.09$ & $1.40 \pm 0.11$ & $1.11 \pm 0.14^{*}$ \\
& $5.01 \pm 0.35$ & $3.19 \pm 0.22$ & $1.82 \pm 0.22 \ddagger$ \\
& $10.00 \pm 1.01$ & $7.40 \pm 0.91$ & $2.60 \pm 0.40 \S$ \\
& $19.99 \pm 1.52$ & $17.44 \pm 1.40$ & $2.55 \pm 0.77 \S$ \\
\hline
\end{tabular}

Livers of 8-wk-old lean and $o b / o b$ mice were perfused for 60 min, as described in Fig. 1 and Table I. Insulin removal was determined at the steady state as detailed in Methods. Liver weights were: controls, $1.28 \mathrm{~g} \pm 0.05 ; o b / o b, 2.67 \mathrm{~g} \pm 0.08$. Flow rates were: controls $1.5 \mathrm{ml} / \mathrm{min}$; $o b / o b 3 \mathrm{ml} / \mathrm{min}$. Values are the means of four to eight experiments \pm SEM. Lean versus $o b / o b:{ }^{*} P<0.05 ; \ddagger P<0.01 ; \S P<0.025$.

tions and as shown by Table III, liver weights, flow rates, insulin concentrations, and infusion rates were all similar. In spite of this, the removal of insulin was clearly less in livers obtained from $o b / o b$ mice than in controls.

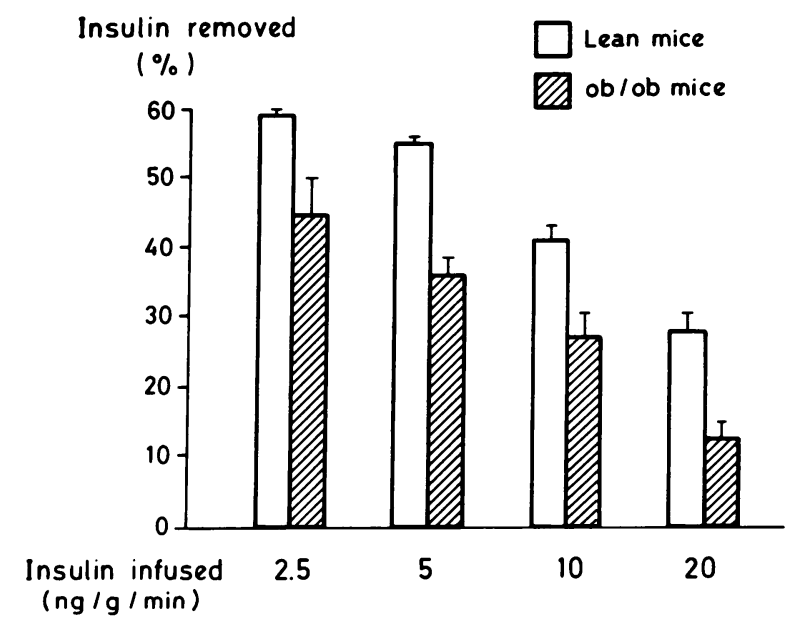

FIGURE 2 Effect of increasing concentrations of insulin infused into the portal vein upon its removal by perfused livers of 8-wk-old lean (open bars) or $o b / o b$ (hatched bars) mice. Insulin removal was determined at the steady state as described in Fig. 1 and in Methods, and is expressed as percent of insulin infused into the portal vein. The flow rates were adjusted to $1.5 \mathrm{ml} / \mathrm{min}$ for controls and $3 \mathrm{ml} /$ min for livers of $o b / o b$ mice. Each bar represents the mean of at least four experiments. Lean versus ob/ob: $P<0.005$; $P<0.0005 ; P<0.025 ; P<0.005$ from left to right, respectively. 
TABLE III

Insulin Removal by Perfused Livers, Matched for Weight, of Lean and ob/ob Mice

\begin{tabular}{ccccccc}
\hline Animals & $\begin{array}{c}\text { Perfused } \\
\text { liver weight }\end{array}$ & Flow rate & $\mathrm{I}_{\text {in }}$ & $\mathrm{I}_{\text {out }}$ & $\mathrm{I}_{\text {in }}-\mathrm{I}_{\text {out }}$ & Insulin removal \\
\hline & $\mathrm{g}$ & $\operatorname{ml} / \min$ & $n g / \mathrm{g} / \mathrm{min}$ & $n g / g / \min$ & $n g / g / \min$ & $\%$ \\
Lean & $1.17 \pm 0.04$ & 1.5 & $5.12 \pm 0.03$ & $2.29 \pm 0.06$ & $2.83 \pm 0.08$ & $55.2 \pm 1.3$ \\
ob/ob & $1.28 \pm 0.07$ & 1.5 & $4.97 \pm 0.04$ & $2.99 \pm 0.21$ & $1.98 \pm 0.22$ & $39.8 \pm 4.0^{*}$ \\
\hline
\end{tabular}

Livers from 8-wk-old lean and $o b / o b$ mice were perfused as described in Fig. 1 and Table I. Immediately after the establishment of perfusion, livers of $o b / o b$ mice were ligated to exclude from circulation about half of their mass $(1.39 \mathrm{~g} \pm 0.09 \mathrm{SEM})$, which was removed surgically. Insulin removal was determined at the steady state as described in Methods. Values are the means of three experiments \pm SEM. ${ }^{*} P<0.0125$.

Since $o b / o b$ mice are continuously exposed to high circulating insulin levels in vivo, it was thought that the observed anomaly in their hepatic insulin removal might be secondary to hyperinsulinemia. To test such an hypothesis, insulin removal by livers of untreated $o b / o b$ mice was compared to that of livers obtained from $o b / o b$ mice, in which insulinemia had been decreased, before perfusion, by streptozotocin treatment, by fasting, or by administration of AIS.

Effect of lowering or "neutralizing" hyperinsulinemia of ob/ob mice upon removal of insulin by subsequently perfused livers. As shown in Table IV, treatment of $o b / o b$ mice with streptozotocin resulted in a marked decrease in circulating insulin and in a rise in plasma glucose concentrations. The fall in plasma insulin levels observed in the streptozotocin-treated $o b / o b$ mice was paralleled by a marked increase in insulin removal by their subsequently perfused livers, when compared to that observed in untreated $o b / o b$ mice (Table IV). A similar relationship was observed when circulating insulin levels were decreased by fasting, as illustrated in Table V. Thus, after 2 days of fasting, insulin removal by livers of $o b / o b$ mice was greater than that observed in fed $o b / o b$ animals. When fasting was extended to 7 days, perfused livers of $o b / o b$ mice exhibited an insulin removal much greater than that of fed $o b / o b$ mice and, although comparison of absolute values from different experimental days should be interpreted with caution, rather similar to that observed in livers of lean controls perfused with the same insulin concentration, i.e. $5 \mathrm{ng} / \mathrm{g} / \mathrm{min}$. (Table $\mathrm{V}$; compare with Fig. 2).

Administration of AIS to $o b / o b$ mice resulted, as shown in Table VI, in a marked increase in plasma glucose levels and, although not shown in the table, by a concomitant rise in plasma free fatty acid concentrations (untreated $o b / o b, 0.7 \pm 0.1 \mathrm{mM}$; AIS-treated $o b / o b, 1.1 \pm 0.1 \mathrm{mM} ; n=3)$. Moreover, $2 \mathrm{~h}$ after AIS injection, the removal of insulin was much greater in perfused livers obtained from AIS-treated $o b / o b$ than in those from untreated $o b / o b$ mice.

Effect of lowering or "neutralizing" insulinemia of lean mice upon removal of insulin by subsequently perfused livers. After a 12-h fast, lean mice showed a marked fall in circulating insulin and plasma glucose levels, and

TABLE IV

Effect of Streptozotocin Treatment upon Insulin Removal by Subsequently Perfused Livers of ob/ob Mice

\begin{tabular}{|c|c|c|c|c|c|c|}
\hline & \multicolumn{2}{|c|}{ Plasma levels } & \multicolumn{4}{|c|}{ Liver perfusion } \\
\hline & IRI & Glucose & $I_{\text {in }}$ & Iout & $I_{\text {in }}-I_{\text {out }}$ & Insulin removal \\
\hline & $n g / m l$ & $m g / 100 m l$ & $n g / g / \min$ & $n g / g / \min$ & $n g / g / \min$ & $\%$ \\
\hline Untreated & $25.1 \pm 2.1$ & $195.7 \pm 33.1$ & $10.15 \pm 0.43$ & $7.72 \pm 0.62$ & $2.43 \pm 0.50$ & $23.9 \pm 4.5$ \\
\hline Streptozotocin-treated & $3.5 \pm 0.4$ & $475.3 \pm 37.7$ & $10.20 \pm 0.83$ & $6.60 \pm 0.70$ & $3.60 \pm 0.55$ & $35.3 \pm 2.3^{*}$ \\
\hline Untreated & & & $25.05 \pm 0.85$ & $21.31 \pm 0.72$ & $3.74 \pm 0.61$ & $14.9 \pm 0.9$ \\
\hline Streptozotocin-treated & & & $25.50 \pm 1.51$ & $18.75 \pm 1.12$ & $6.75 \pm 1.21$ & $26.5 \pm 2.2 \ddagger$ \\
\hline
\end{tabular}

$o b / o b$ mice were injected intraperitoneally with streptozotocin $(200 \mathrm{mg} / \mathrm{kg}$ body weight $)$ and the experiment were carried out 11 days after the treatment. Plasma glucose and insulin levels were measured immediately before experiments. Livers were perfused for $60 \mathrm{~min}$ as described in Fig. 1 and Table I. Insulin removal was determined at the steady state as detailed in Methods and expressed as percent of insulin infused into the portal vein. Liver weights were: untreated mice, $2.91 \mathrm{~g} \pm 0.13$; streptozotocintreated mice, $2.62 \mathrm{~g} \pm 0.14$. Flow rate was $3 \mathrm{ml} / \mathrm{min}$ in both groups. Values are the means of four experiments $\pm \mathrm{SEM}{ }^{*} P<0.05$; $\ddagger P<0.0005$. 
TABLE V

Effect of Fasting upon Insulin Removal by Subsequently Perfused Livers of ob/ob Mice

\begin{tabular}{|c|c|c|c|c|c|c|}
\hline & \multicolumn{2}{|c|}{ Plasma levels } & \multicolumn{4}{|c|}{ Liver perfusion } \\
\hline & IRI & Glucose & $I_{\text {in }}$ & Iout & $I_{\text {in }}-I_{\text {out }}$ & Insulin removal \\
\hline & $n g / m l$ & $\mathrm{mg} / 100 \mathrm{ml}$ & $n g / g / \min$ & $n g / g / \min$ & $n g / g / \min$ & $\%$ \\
\hline Fed & $16.17 \pm 2.80$ & $290.7 \pm 36.4$ & $4.99 \pm 0.70$ & $3.25 \pm 0.53$ & $1.74 \pm 0.32$ & $34.9 \pm 1.3$ \\
\hline 2 days fasted & $4.07 \pm 0.46$ & $165.0 \pm 25.0$ & $5.04 \pm 0.08$ & $2.62 \pm 0.10$ & $2.42 \pm 0.11$ & $48.0 \pm 1.8^{*}$ \\
\hline 7 days fasted & $1.81 \pm 0.57$ & $53.8 \pm 13.2$ & $4.98 \pm 0.09$ & $1.96 \pm 0.22$ & $3.02 \pm 0.21$ & $60.6 \pm 3.9 \ddagger$ \\
\hline Fed & & & $10.31 \pm 0.81$ & $7.42 \pm 0.92$ & $2.89 \pm 1.10$ & $28.0 \pm 1.4$ \\
\hline 2 days fasted & & & $9.72 \pm 0.11$ & $5.78 \pm 0.16$ & $3.94 \pm 0.08$ & $40.5 \pm 1.0 \ddagger$ \\
\hline
\end{tabular}

Livers from 8-wk-old fed, 2- or 7-days-fasted $o b / o b$ mice were perfused as described in Fig. 1, Table I, and Methods. Insulin was infused into the portal vein at the concentrations indicated. Insulin removal was determined at the steady state. Liver weights were: fed $o b / o b, 2.5 \mathrm{~g} \pm 0.04 ; 2$-days-fasted $o b / o b, 2.09 \mathrm{~g} \pm 0.06 ; 7$-days-fasted $o b / o b, 1.29 \mathrm{~g} \pm 0.05$. Flow rates were adjusted to $3 \mathrm{ml} / \mathrm{min}$, except for the 7 -days-fasted group $(1.5 \mathrm{ml} / \mathrm{min})$. Values are the means of four experiments $\pm S E M$; fasted versus fed: ${ }^{*} P<0.0025 ; \ddagger P<0.0005$.

a concomitant rise in hepatic insulin removal at both concentrations of insulin tested, compared to normal fed mice (Table VII).

In contrast to what was observed in $o b / o b$ mice, when circulating insulin levels of lean mice were neutralized by AIS administration in vivo, no change in insulin removal by subsequently perfused livers was observed, as shown in Table VIII. This lack of change was not due to ineffective AIS, since plasma glucose concentrations rose (Table VIII) as did those of free fatty acids (untreated lean mice, $0.6 \pm 0.1 \mathrm{mM}$; AIS-treated lean mice, $1.3 \pm 0.2 \mathrm{mM} ; n=6$ ).

It was thought unlikely that hepatic insulin removal could be influenced by the blood sugar prevailing before perfusion, since the removal process was found to be increased either by fasting (low blood sugar) or AIS administration (high blood sugar) (Tables IV-VII). Actually, when $200 \mathrm{mg} / 100 \mathrm{ml}$ glucose was directly added to the perfusion medium, hepatic insulin removal was not influenced in perfused livers from either fed or fasted lean mice (Table IX). Such results are in keeping with similar observations made with an in vivo technique (19).

\section{DISCUSSION}

Since the insulin produced by the $\beta$-cells of the pancreas must pass through the liver before its entry into the peripheral blood, the hepatic removal of the hormone may play a role in determining the final peripheral insulin concentration. Previous studies $(10,11)$ have indeed indicated that an inverse correlation appears to exist between the insulin concentration reaching the portal vein and the proportion of insulin removal by the liver. The present experiments have considerably substantiated the existence of such a correlation between plasma insulin concentration and hepatic insulin re- moval, and have extended it to livers of both lean and obese-hyperglycemic (ob/ob) mice.

This study indicates that in livers of both lean and obese-hyperglycemic mice, the removal of insulin increases as the concentration of the hormone in the portal vein increases, until the process eventually becomes saturated (Table II), as previously suggested for perfused livers of normal rats (9). Considerably lower insulin concentrations were required to reach saturation in livers from $o b / o b$ than from normal mice (Table II). The limited capacity of the removal process may be best illustrated by the finding that the percentage of insulin removed actually decreased when increasing concentrations of the hormone reached the liver (Fig. 2). Moreover, the removal of insulin by livers of $o b / o b$ mice was considerably less efficient than that seen in livers of lean mice, for all insulin concentrations tested (Fig. 2).

On the basis of such experiments, it is concluded that the efficiency of insulin removal by the liver is influ-

TABLE VI

Effect of AIS Administration upon Insulin Removal by Subsequently Perfused Livers of ob/ob Mice

\begin{tabular}{lccccc}
\hline & & \multicolumn{5}{c}{ Liver perfusion } \\
\cline { 3 - 6 } & Plasma & & & & Insulin \\
& glucose & $I_{\text {in }}$ & $I_{\text {out }}$ & $I_{\text {in }}-I_{\text {out }}$ & removal \\
\hline & $m g / 100 m l$ & $n g / g / m i n$ & $n g / g / m i n$ & $n g / g / m i n$ & $\%$ \\
Untreated & $206 \pm 11$ & $5.02 \pm 0.31$ & $3.61 \pm 0.09$ & $1.41 \pm 0.22$ & $28.0 \pm 4.1$ \\
AIS-treated & $464 \pm 97$ & $5.11 \pm 0.40$ & $3.06 \pm 0.08$ & $2.05 \pm 0.06$ & $40.1 \pm 2.9 *$ \\
\hline
\end{tabular}

11-wk-old $o b / o b$ mice were injected into a tail vein with AIS, or with normal guinea pig serum (untreated $o b / o b$ ). 2 h later, livers were perfused as described in Fig. 1. Table I, and Methods. Insulin removal was determined at the steady state and expressed as percent of insulin infused into the portal vein. Liver weights were: untreated mice, $2.67 \mathrm{~g} \pm 0.08$; A IS-treated mice, $2.78 \mathrm{~g} \pm 0.09$. Flow rate was $3 \mathrm{ml} / \mathrm{min}$. Values are the means of three experiments $\pm \mathrm{SEM} ; * P<0.05$ 
TABLE VII

Effect of Fasting upon Insulin Removal by Subsequently Perfused Livers of Lean Mice

\begin{tabular}{|c|c|c|c|c|c|c|}
\hline & \multicolumn{2}{|c|}{ Plasma levels } & \multicolumn{4}{|c|}{ Liver perfusion } \\
\hline & IRI & Glucose & $I_{\text {in }}$ & Iout & $I_{\text {in }}-I_{\text {out }}$ & Insulin removal \\
\hline & $n g / m l$ & $\mathrm{mg} / 100 \mathrm{ml}$ & $n g / g / \min$ & $n g / g / \min$ & $n g / g / \min$ & $\%$ \\
\hline $\begin{array}{l}\text { Fed } \\
\text { Fasted }\end{array}$ & $\begin{array}{l}0.71 \pm 0.06 \\
0.34 \pm 0.02\end{array}$ & $\begin{array}{c}163 \pm 10 \\
58 \pm 2\end{array}$ & $\begin{array}{l}4.98 \pm 0.03 \\
5.06 \pm 0.09\end{array}$ & $\begin{array}{l}2.65 \pm 0.06 \\
1.85 \pm 0.07\end{array}$ & $\begin{array}{l}2.33 \pm 0.02 \\
3.21 \pm 0.06\end{array}$ & $\begin{array}{l}46.7 \pm 0.9 \\
63.4 \pm 4.5^{*}\end{array}$ \\
\hline $\begin{array}{l}\text { Fed } \\
\text { Fasted }\end{array}$ & & & $\begin{array}{l}25.30 \pm 1.31 \\
26.05 \pm 0.90\end{array}$ & $\begin{array}{l}19.19 \pm 0.09 \\
15.53 \pm 0.08\end{array}$ & $\begin{array}{r}6.11 \pm 0.08 \\
10.52 \pm 0.07\end{array}$ & $\begin{array}{l}24.1 \pm 4.8 \\
40.4 \pm 3.2 \ddagger\end{array}$ \\
\hline
\end{tabular}

Livers from fed and 12-14-hr-fasted, 8-wk-old lean mice were perfused as described in Fig. 1, Table I, and Methods. Insulin removal was determined at the steady state and expressed as percent of insulin infused into the portal vein. Liver weights were: fed mice, $1.16 \mathrm{~g} \pm 0.05$; fasted mice, $0.81 \mathrm{~g} \pm 0.03$. Flow rate was $1.5 \mathrm{ml} / \mathrm{min}$. Values are the means of five experiments \pm SEM. ${ }^{*} P<0.005 ; \ddagger P<0.0125$.

enced by the concentration of hormone delivered to it, decreasing when the concentration of insulin reaching the liver is increased. The chronic hyperinsulinemia of the $o b / o b$ mice (20) may, therefore, be partly responsible for the altered effectiveness in their hepatic insulin removal process. The latter hypothesis appears to be validated by the finding that when circulating insulin levels of the $o b / o b$ mice are lowered by streptozotocin treatment (Table IV), by fasting (Table V), or by anti-insulin treatment (Table VI), the removal of insulin is markedly increased. The observation that the removal of insulin by livers of lean mice can also be increased by fasting, concomitant with a sizable decrease in circulating insulin levels, suggests that the observed impairment in hepatic removal of $o b / o b$ mice may only represent an amplification of a normally occurring process. This is in keeping with previous experiments from these laboratories indicating that the many anomalies of liver metabolism in $o b / o b$ mice merely represent overstimulation or overinhibition, due to hyperinsulinemia, of processes that occur normally (13). Although the anomaly of insulin handling by livers of $o b / o b$ mice can be reversed within $2 \mathrm{~h}$ (Table VI), such a re- versal cannot be observed in livers of lean mice (Table VIII). This indicates that deviation of insulin removal capacity from normal values takes time to occur, (e.g. effect of a 12-14-h fast versus no effect of a 2-h AIS treatment in lean mice), while normalization of this process from already abnormal values can be readily observed, as seen in experiments with $o b / o b$ mice. That the process of hepatic insulin removal is not influenced by glucose is indicated by the finding that this process is augmented at a time when blood sugar is either high (streptozotocin or AIS treatment) or low (fasting) (Table IV-VII), and is not altered by addition of glucose to the perfusion medium (Table IX).

The nature of hepatic insulin removal is ill-defined. It may represent intermingled processes such as specific insulin-receptor interaction, actual uptake or trapping of the hormone at some unspecific site(s), or destruction or alteration of the hormone so that it lost its immunoreactivity. It is of note that changes in insulin removal and their relationship to hyperinsulinemia are qualitatively similar to those observed in the binding of insulin to isolated cells or membranes. Thus, it has been reported that insulin binding to various membrane types

TABLE VIII

Lack of Effect of AIS Treatment on Insulin Removal by Subsequently Perfused Livers of Lean Mice

\begin{tabular}{lccccc}
\hline & & \multicolumn{4}{c}{ Liver perfusion } \\
\cline { 3 - 6 } & Plasma glucose & $\mathrm{I}_{\text {in }}$ & I out & $\mathrm{I}_{\text {in }}-\mathrm{I}_{\text {out }}$ & Insulin removal \\
\hline \multirow{3}{*}{ Untreated } & $m g / 100 \mathrm{ml}$ & $n g / \mathrm{g} / \mathrm{min}$ & $n g / \mathrm{g} / \mathrm{min}$ & $n g / \mathrm{g} / \mathrm{min}$ & $\%$ \\
AIS-treated & $161.8 \pm 3.6$ & $4.98 \pm 0.07$ & $2.97 \pm 0.07$ & $2.01 \pm 0.04$ & $40.3 \pm 0.8$ \\
& $304.5 \pm 4.0$ & $5.04 \pm 0.08$ & $2.93 \pm 0.06$ & $2.11 \pm 0.05$ & $41.8 \pm 1.1^{*}$ \\
\hline
\end{tabular}

11-wk-old lean mice were injected into a tail vein with AIS, or with normal guinea pig serum (untreated lean). $2 \mathrm{~h}$ later, livers were perfused as described in Fig. 1, Table I, and Methods. Insulin removal was determined at the steady state and expressed as percent of insulin into the portal vein. Liver weights were: untreated mice, $1.33 \mathrm{~g} \pm 0.05$; AIS-treated mice, $1.25 \mathrm{~g} \pm 0.06$. Flow rate was $1.5 \mathrm{ml} / \mathrm{ml}$. Values are the means of six experiments \pm SEM. ${ }^{*} \mathrm{NS}$. 
TABLE IX

Lack of Effect of Added Glucose on Insulin Removal by Perfused Livers of Lean Mice

\begin{tabular}{lccccc}
\hline Animals & $\begin{array}{c}\text { Perfusate } \\
\text { glucose }\end{array}$ & $\mathrm{I}_{\text {in }}$ & $\mathrm{I}_{\text {out }}$ & $\mathrm{I}_{\text {in }}-\mathrm{I}_{\text {out }}$ & $\begin{array}{c}\text { Insulin } \\
\text { removal }\end{array}$ \\
\hline \multirow{4}{*}{ Fed lean } & $m g / 100 \mathrm{ml}$ & $n g / \mathrm{g} / \mathrm{min}$ & $n g / g / m i n$ & $n g / g / m i n$ & $\%$ \\
& 0 & $10.02 \pm 0.06$ & $5.85 \pm 0.05$ & $4.17 \pm 0.04$ & $41.6 \pm 0.6$ \\
Fasted lean & 200 & $10.03 \pm 0.08$ & $5.79 \pm 0.09$ & $4.24 \pm 0.07$ & $42.2 \pm 2.4^{*}$ \\
& 0 & $10.41 \pm 0.09$ & $5.21 \pm 0.07$ & $5.20 \pm 0.05$ & $49.9 \pm 2.2$ \\
& 200 & $10.58 \pm 0.08$ & $5.12 \pm 0.09$ & $5.46 \pm 0.12$ & $51.6 \pm 3.1^{*}$
\end{tabular}

Livers of fed and 12-14-h-fasted, 8-wk-old lean mice were perfused as described in Fig. 1, Table I, and Methods, at a flow rate of $1.5 \mathrm{ml} / \mathrm{min}$. Insulin removal was determined at the steady state in the presence or absence of glucose in the perfusion medium, and expressed as percent of insulin infused into the portal vein. Liver weights were: fed mice, $1.13 \mathrm{~g} \pm 0.04$; fasted mice, $0.88 \mathrm{~g} \pm 0.03$. Values are the means of at least six experiments $\pm S E M$ *NS.

obtained from $o b / o b$ mice was much lower than that of controls (21-23), and that it was restored towards normal by fasting as well as by streptozotocin treatment (24). In a similar fashion, exposure of isolated cultured human lymphocytes to insulin for $5-16 \mathrm{~h}$ produced a decrease in their insulin receptor concentrations, although acute exposure to the hormone (i.e. up to $2 \mathrm{~h}$ ) was without effect (25).

The insulin removal reported in the present study, as well as the differences noted between livers of lean and $o b / o b$ mice, may thus reflect changes in insulin receptors, alone or combination with other processes of insulin handling. Although it has been suggested that the degradation of labeled insulin by liver plasma membranes of $o b / o b$ mice is somewhat less than that of controls, it has been emphasized that such differences in degradation are small compared to the observed differences in binding (26).

Hyperinsulinemia of the $o b / o b$ mice appears to occur early in the development of the syndrome (20), and to be at the origin of several metabolic anomalies (13, 14). Although it is very unlikely that the liver could play any primary role in hyperinsulinism, it is of interest to observe from these experiments that it does not adapt to hyperinsulinemia usefully but undergoes changes only likely to make hyperinsulinemia worse. Thus, the anomaly of insulin removal observed in livers of $o b / o b$ mice could be yet another factor in the vicious metabolic cycles that eventually result in obesity and insulin resistance as previously reported $(13,14)$. It is conceivable that such alterations might occur in humans, and thus be important in the pathophysiology of obesity, linked or unlinked to diabetes.

\section{ACKNOWLEDGMENTS}

We are greatly indebted to Mrs. Hilke Petersen for her excellent and dedicated technical assistance. We are grateful to Dr. P. Trueheart for her help and suggestions during the setting up of the insulin radioimmunoassay technique. The stimulating comments of Drs. L. B. Salans and D. B. Martin, visiting professors at the Institut de Biochimie clinique during the writing of this paper, are also gratefully acknowledged. We thank particularly Miss May Kassem for her good will and patience in typing this manuscript.

This work has been supported by Grant No. 3.552.71 of the Fonds National Suisse de la Recherche Scientifique, Berne, Switzerland, and by a grant-in-aid of Zyma SA, Nyon, Switzerland. Thanks are extended for this grant to Drs. Grumbach, Vonder Mühll and R. Horn, of Zyma SA.

\section{REFERENCES}

1. Field, J. B. 1972. Insulin extraction by the liver. Handb. Physiol. Section 7: endocrinology. 1: 505-513.

2. Wadell, W. R., and K. E. Sussman. 1967. Plasma insulin after diversion of portal and pancreatic venous blood to vena cava. J. Appl. Physiol. 22: 808-812.

3. Madison, L. L., and N. Kaplan. 1958. The hepatic binding of $\mathrm{I}^{131}$-labeled insulin in human subjects during a single transhepatic circulation. J. Lab. Clin. Med. 52: 927. (Abstr.).

4. Kaden, M., P. Harding, and J. B. Field. 1973. Effect of intraduodenal glucose administration on hepatic extraction of insulin in the anaesthetized dog. J. Clin. Invest. 52: 2016-2028.

5. Mortimore, G. E., and F. Tietze. 1959. Studies on the meclanism of capture and degradation of insulin- $\mathrm{I}^{131}$ by the cyclically perfused rat liver. Ann. N.Y. Acad. Sci. 82: 329-337.

6. Solomon, S. S., L. F. Fenster, J. W. Ensinck, and R. H. Williams. 1967. Clearance studies of insulin and nonsuppressible insulin-like activity (NSILA) in the rat liver. Proc. Soc. Exp. Biol. Med. 126: 166-169.

7. Stoll, R. W., J. L. Touber, L. A. Menahan, and R. H. Williams. 1970. Clearance of porcine insulin, proinsulin, and connecting peptide by the isolated rat liver. Proc. Soc. Exp. Biol. Med. 133: 894-896.

8. Gershoff, S. N., N. L. Weich, and H. A. Antoniades. 1970. Production of nonimmunoassayable insulin-like material by perfused rat liver. Diabetes. 19: 296-301.

9. Mondon, C. E., J. M. Olefsky, C. B. Dolkas, and G. M. Reaven. 1975. Removal of insulin by perfused rat liver: effect of concentration. Metab. Clin. Exp. 24: 153-160.

10. Marshall, A., R. L. Gingerich, P. H. Wright. 1970. Hepatic metabolism of insulin in vitro. Clin. Res. 18: 33. (Abstr.).

11. McCarroll, A. M., and K. D. Buchanan. 1973. Insulin clearance by the isolated perfused livers of insulin deficient rats. Diabetologia. 9: 457-460.

12. Stauffacher, W., L. Orci, D. P. Cameron, I. M. Burr, and A. E. Renold. 1971. Spontaneous hyperglycemia and/or obesity in laboratory rodents: an example for the possible usefulness of animal disease models with both genetic and environmental components. Recent Prog. Horm. Res. 27 : 41-95.

13. Assimacopoulos-Jeannet, F., A. Singh, Y. Le Marchand, E. G. Loten, and B. Jeanrenaud. 1974. Abnormalities in lipogenesis and triglyceride secretion by perfused livers of obese-hyperglycaemic $(o b / o b)$ mice: relationship with hyperinsulinaemia. Diabetologia. 10: 155-162.

14. Loten, E. G., A. Rabinovitch, and B. Jeanrenaud. 1974. In vivo studies on lipogenesis in obese-hyperglycaemic $(o b / o b)$ mice: possible role of hyperinsulinaemia. Diabetologia. 10 : $45-52$.

15. Assimacopoulos-Jeannet, F., J. H. Exton, and B. Jean- 
renaud. 1973. Control of gluconeogenesis and glycogenolysis in perfused livers of normal mice. Am. J. Physiol. $225: 25-32$.

16. Chen, R. F. 1967. Removal of fatty acids from serum albumin by charcoal treatment. J. Biol. Chem. 242: 173181.

17. Herbert, V., K-S. Lau, C. W. Gottlieb, S. J. Bleicher. 1965. Coated charcoal immunoassay of insulin. J. Clin. Endocrinol. Metab. 25: 1375-1384.

18. Wienand, J. 1970. Aspects qualitatifs et quantitatifs du métabolisme lipidique de la souris normale et de la souris congénitalement obèse. Editions Arscia. Brussels, Belgium.

19. Olefsky, J. M., T. Batchelder, S. Colome, and G. M. Reaven. 1974. Effect of intravenous glucose infusion on plasma insulin removal rate. Metab. Clin. Exp. 23: 543548.

20. Westman, S. 1968. Development of the obese-hyperglycaemic syndrome in mice. Diabetologia. 4: 141-149.

21. Kahn, C. R., D. M. Neville, Jr., P. Gordon, P. Freychet, and J. Roth. 1972. Insulin receptor defect in insulin re- sistance: studies in the obese-hyperglycemic mouse. Biochem. Biophys. Res. Commun. 48: 135-142.

22. Kahn, C. R., D. M. Neville, Jr., and J. Roth. 1973. Insulin-receptor interaction in the obese-hyperglycemic mouse. A model of resistance. J. Biol. Chem. 248: 244 250.

23. Freychet, P., M. H. Laudat, P. Laudat, G. Rosselin. C. R. Kahn, P. Gordon, and J. Roth. 1972. Impairment of insulin binding to the fat cell plasma membrane in the obese hyperglycemic mouse. FEBS (Fed. Eur. Biochem. Soc.) Lett. 25 : 339-342.

24. Freychet, P. 1975. Recent studies on insulin-receptor interactions. Isr. J. Med. Sci. 11: 679-686.

25. Gavin, J. R., III, J. Roth, D. M. Neville, Jr., P. de Meyts, and D. N. Buell. 1974. Insulin-dependent regulation of insulin receptor concentrations: a direct demonstration in cell culture. Proc. Natl. Acad. Sci. U. S. A. $71: 84-88$.

26. Soll, A. H., C. R. Kahn, D. M. Neville, Jr., and J. Roth. 1975. Insulin receptor deficiency in genetic and acquired obesity. J. Clin. Invest. 56: 769-780. 